Document downloaded from:

http://hdl.handle.net/10251/37029

This paper must be cited as:

Alija Sánchez, S.; Torrijo Echarri, FJ.; Quinta-Ferreira, M. (2013). Study of the unexpected collapse of the Ampurdán tunnel (Spain) using a finite elements model. Bulletin of Engineering Geology and the Environment. 1-12. doi:10.1007/s10064-013-0534-z.

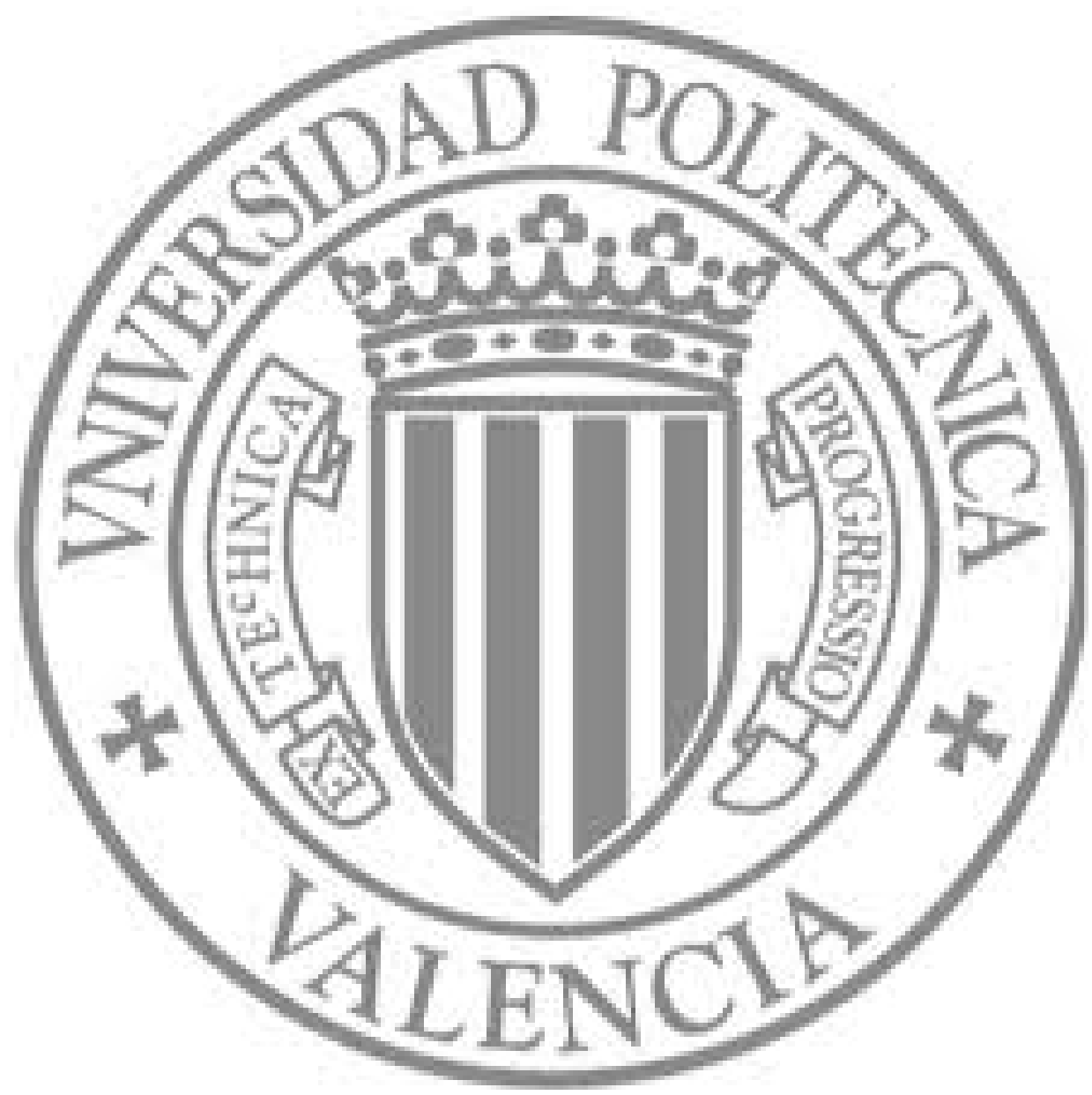

The final publication is available at

http://dx.doi.org/10.1007/s10064-013-0534-z

Copyright Springer Verlag (Germany) 


\section{Bulletin of Engineering Geology and the Environment Study of the unexpected collapse of Ampurdán Tunnel (Spain) using Finite Element Model \\ --Manuscript Draft--}

\begin{tabular}{|c|c|}
\hline Manuscript Number: & BOEG-D-13-00081 \\
\hline Corresponding Author: & $\begin{array}{l}\text { Francisco Javier Torrijo, Ph.D. } \\
\text { Universidad Politécnica de Valencia } \\
\text { Valencia, Valencia SPAIN }\end{array}$ \\
\hline \multicolumn{2}{|l|}{$\begin{array}{l}\text { Corresponding Author Secondary } \\
\text { Information: }\end{array}$} \\
\hline Corresponding Author's Institution: & Universidad Politécnica de Valencia \\
\hline \multicolumn{2}{|l|}{$\begin{array}{l}\text { Corresponding Author's Secondary } \\
\text { Institution: }\end{array}$} \\
\hline \multirow[t]{3}{*}{ Order of Authors: } & Santiago Alija, Ph.D. \\
\hline & Francisco Javier Torrijo, Ph.D. \\
\hline & Mario Quinta-Ferreira, Ph.D. \\
\hline \multicolumn{2}{|c|}{ Order of Authors Secondary Information: } \\
\hline Abstract: & $\begin{array}{l}\text { The paper presents the case study of the Ampurdán tunnel that suffered an } \\
\text { unexpected partial collapse during construction, due to the weathering of the claystone } \\
\text { groundmass, after excavation and wetting by infiltration water. To overcome the } \\
\text { problems encountered, the finite elements model was used to understand the } \\
\text { behaviour of the tunnel and surrounding ground, to determine the geotechnical } \\
\text { properties that lead to failure, allowing to choose suitable procedures for the } \\
\text { construction of the tunnel. The parametric study performed simulated the deformations } \\
\text { measured in situ and related with the tunnel collapse. The geotechnical parameters } \\
\text { used for the weathered claystone, when compared with the ones of intact situation, } \\
\text { correspond to a wide range of reductions between } 8 \% \text { in the apparent density and in } \\
\text { the effective friction angle, up to } 40 \% \text { in the effective cohesion and } 56 \% \text { in the Young } \\
\text { modulus. }\end{array}$ \\
\hline \multirow[t]{2}{*}{ Suggested Reviewers: } & $\begin{array}{l}\text { René Gómez } \\
\text { Researcher, Confederación Hidrográfica del Ebro } \\
\text { rgomez@chebro.es } \\
\text { He is a specialist in geotechnical and engineering geology, , well known in Spain }\end{array}$ \\
\hline & $\begin{array}{l}\text { Luis Arlegui, PhD } \\
\text { Researcher and professor, Universidad de Zaragoza } \\
\text { arlegui@posta.unizar.es } \\
\text { He's a professor and researcher in Engineering Geology }\end{array}$ \\
\hline
\end{tabular}




\title{
Study of the unexpected collapse of Ampurdán Tunnel (Spain) using Finite Element Model
}

\author{
S. Alija ${ }^{\mathrm{a}}$, F.J. Torrijo $^{\mathrm{b}}$, M. Quinta-Ferreira ${ }^{\mathrm{c}}$ \\ ${ }^{a}$ Geosciences Center, University of Coimbra \\ Largo Marquês de Pombal \\ 3000-272 Coimbra, Portugal \\ Phone: +351239860500 Fax: +351239860501 \\ santiagoalija@gmail.com \\ ${ }^{b}$ Department of Earth Engineering, Universidad Politécnica de Valencia \\ 46022 Valencia, Spain \\ ${ }^{c}$ Department of Earth Sciences, Geosciences Center, University of Coimbra \\ Largo Marquês de Pombal \\ 3000-272 Coimbra, Portugal \\ Phone: +351912563901 Fax: +351239860501 \\ mqf@dct.uc.pt
}

\begin{abstract}
The paper presents the case study of the Ampurdán tunnel that suffered an unexpected partial collapse during construction, due to the weathering of the claystone groundmass, after excavation and wetting by infiltration water. To overcome the problems encountered, the finite elements model was used to understand the behaviour of the tunnel and surrounding ground, to determine the geotechnical properties that lead to failure, allowing to choose suitable procedures for the construction of the tunnel. The parametric study performed simulated the deformations measured in situ and related with the tunnel collapse. The geotechnical parameters used for the weathered claystone, when compared with the ones of intact situation, correspond to a wide range of reductions between $8 \%$ in the apparent density and in the effective friction angle, up to $40 \%$ in the effective cohesion and $56 \%$ in the Young modulus.
\end{abstract}

Keywords Tunnel collapse, Softrock, Claystone, Finite element method 


\section{Introduction}

The problems occurred in the Ampurdán tunnel during its construction are present, whilst emphasising the usefulness of computational tools based on finite elements.

The failure can be mainly related to the fast weathering of the tertiary materials on which the tunnel was built. The use of a finite element modelling program (Plaxis) allowed to identify the geotechnical parameters responsible for the problems occurred during the construction works (Wang et al. 2012).

The Ampurdán tunnel is located in the province of Girona and is part of the highspeed line between Madrid-Zaragoza-Barcelona-French border. It is a doubletrack tunnel, which has a length of $649 \mathrm{~m}$ and a maximum vertical offset of $24 \mathrm{~m}$.

\section{Geological framework}

The study area is located in the Neogene tectonic depression of Ampurdán's, which is included in the Catalan Traverse System. The tunnel was built in the Miocene materials filling the depression (Agustí et al. 1994; IGME 1995). This depression was originated during a distension process in favour of normal faults, mainly oriented NW-SE, leading to the formation of a basin that was filled with materials eroded from the surrounding reliefs.

Along the tunnel route, only one lithostratigraphic unit is intersected: the Ampurdán Formation $\left(\mathrm{M}_{\mathrm{A}}\right)$. This series of detrital origin is predominantly constituted by red claystone and siltstone, with interbedded arkosic sandstones and conglomerates constituting paleo channels of the alluvial fans that filled the Ampurdán basin.

In general, there is a gradation of materials from the most detrital, and large grain size, at the edge of the basin, South of the study area, to the finer materials with carbonated levels of caliche, toward the Northern basin centre, where more distal facies have been deposited. From the hydrogeological viewpoint, due to the predominance of mudstone materials, this formation is almost impermeable. Some 
hanging water tables are associated with the most permeable layers of sand or gravel, interbedded in the clay.

\section{Geotechnical characterisation}

The geotechnical information used in the implementation of the tunnel was provided by site investigation carried out during the design, and by a complementary campaign, executed before the start of the construction works. This last campaign did not entail significant changes in the geotechnical parameters of the Ampurdán Formation $\left(\mathrm{M}_{\mathrm{A}}\right)$. The site investigation allowed to obtaining the main geotechnical parameters of the claystone groundmass (Table 1) and the preparation of the profile presented in Fig. 1.

Table 1 Summary of the geotechnical parameters considered in the design of the Ampurdán tunnel

Fig. 1 Profile of the Ampurdán tunnel. The arrow points the advance direction

\section{The construction project}

The free section of the tunnel defined according to health and comfort criteria was $110 \mathrm{~m}_{2}$. The geometric features of the tunnel cross-section were designed with a circular dome extending until the invert, without differentiating the sidewalls. In Fig. 2 is presented the layout of the tunnel cross-section.

Fig. 2 Cross-section of the tunnel with elephant's foot. I - top heading, II and III - bench, IV invert 
Taking into account the characteristics of the ground and the tunnel dimensions, it was decided that mechanical excavation was the most efficient procedure (López Jimeno 1996). The New Austrian Tunnelling Method (NATM) was selected, and excavation phases were used: excavation of top heading, two lateral bench excavations and an invert excavation phase (Cornejo Álvarez 1988; Díaz Méndez 1997).

To control and verify the stress and strain conditions, a surveillance system was implemented, to ensure an early detection of the tunnel behaviour.

For the selection of the tunnel support, several known empirical methods were considered, based on geomechanical rock mass classifications (Bieniawski 1989; Romana 1997; Barton 2000; Hoek 1998; Hoek \& Brown 1985, 1988). For the Ampurdán Clay unit, the geomechanical parameters considered are: $\mathrm{RMR}=20$; $\mathrm{GSI}=20 ; \mathrm{Q}=0.10$.

In the design of the tunnel support, due to the groundmass homogeneity a single section type was defined. For the portals, a special section was considered. The section types were evaluated using numerical models in 2D.

The main section of the tunnel was identified as type S-III. In this section, the excavation would take place by passes of $0.5-1.0 \mathrm{~m}$. The support would be based on a $5 \mathrm{~cm}$ sealing of shotcrete reinforced with fibres, heavy HEB-160 steel ribs and shotcrete reinforced with fibres $30 \mathrm{~cm}$ thick (excluding the $5 \mathrm{~cm}$ sealing). The excavation would be done by subphases with passes of 1.0 to $2.0 \mathrm{~m}$ extending the support as the excavation progresses.

The portals section (S-E) was considered of "heavy" type, being in a superficial zone, more weathered and decompressed than the interior of the groundmass, due to the previous excavation of the portals slopes and to the reduced tunnel overburden. The proposed S-E section consists of a heavy umbrella of micropiles $20 \mathrm{~m}$ long, $150 \mathrm{~mm}$ drill diameter, spaced $0.5 \mathrm{~m}$ between their axes and reinforced with steel pipes $110 \mathrm{~mm}$ diameter, $8 \mathrm{~mm}$ thick and filled with mortar. The sequence of excavation and support for this section would be similar to that of the S-III with the difference that the steel ribs placed below the umbrella would be of type HEB-180. 
Both sections have an inverted concrete arch with electro-welded mesh 150x150x6 mm. The geometry of the section influences the distribution of stresses acting on the support, as a more circular shape reduces the risk of developing traction in the concrete, making more efficient a section with an inverted arch than a flat invert, especially in terrains of poor geotechnical quality. After the excavation of the bench, the construction continued with the excavation of the inverted arch and the concreting of the ribs foundation pad, as well as starting the lining ring. A summary of the support types defined for the tunnel is presented in the Table 2 .

Table 2 Summary of support types used in Ampurdán tunnel

\section{Instrumentation of the tunnel}

In the New Austrian Tunnelling Method, appropriate auscultation and systematic control of the excavation works and support is essential, requiring the implementation of geometric and topographical monitoring, the measurement of convergences and the auscultation of cross sections. Geometric and topographical monitoring was based on external triangulation and the constant checking of the internal position of the tunnel axis and on the layout of the support elements. The convergence measurements inside the tunnel were controlled in sections equipped with two bolts in the sidewalls for the use of strain gauge tape and a topographic target in the crown. This allowed the control relative movements in the sidewalls, and absolute movements in the crown.

In auscultation cross sections, the control elements are (Fig. 3):

- Total pressure cells: 3 units arranged between the support and the permanent lining in the crown and sidewalls.

- $\quad$ Rod strain gauges: 3 units installed in the crown and sidewalls. Each strain gauge comprised 3 rods of 2, 4 and $6 \mathrm{~m}$ in length, measured from the inner side of the support. 
Fig. 3. Sketch of the cross-section monitoring arrangement. TPC - total pressure cell

\section{The construction}

The excavation works in Ampurdán tunnel began by the North portal (Fig. 1). The support of the portal was done using rockbolts, $12 \mathrm{~m}$ long and $32 \mathrm{~mm}$ in diameter, using a $3 \times 2 \mathrm{~m}$ pattern, and $10 \mathrm{~cm}$ of shotcrete HP-30 reinforced with wire mesh (150x150x6 mm).

Since the start of the excavation, the engineering geology mapping of the tunnel face was done by a resident geologist, aiming to determine the main geotechnical features of the groundmass. He was also in charge of monitoring the instrumentation installed inside the tunnel. The staff responsible for the technical assistance to the tunnel (Alija 2010) also evaluated the data collected.

The initial excavation works confirmed that the Miocene claystone is homogeneous, occasionally with subhorizontal interbedded layers of sandstone, of decimetric thickness. It is important to highlight that the sandstone layers, once intersected, showed abundant flow of water, reducing progressively the flow, without completely stopping, and requiring the use of temporary drainage to allow the construction works on the tunnel. With rainy weather, the flow of the drains increases rapidly, indicating a fissural interconnection from the surface until the sandstone layers. In the portal area, due the presence of water, 50 Swellex rockbolts, $4 \mathrm{~m}$ long ( 25 on each side), were placed in the sidewalls, $1 \mathrm{~m}$ apart (between ribs) with nearly horizontal inclination. These rockbolts were dry-fitted to avoid adding water into the groundmass.

An incident that occurred during the excavation of the portal must be highlighted. At the top heading level, with the support of the last operation in place, a portion of the ground behind the shotcrete and the rockbolts fallen due to the internal erosion of the sandstone layers.

During the first $40 \mathrm{~m}$ of the tunnel excavation, there was a constant presence of water flowing through the sandy layers. This influx reduced as the tunnel 
advanced, but continued throughout the entire construction period, requiring the implementation of border gutters to drain the entrance area.

Once the $20 \mathrm{~m}$ long micropiles umbrella was completed, a beam joining the micropile heads was constructed, and the first steel rib HEB-180 of the tunnel (rib $0)$ was placed.

In subsequent excavation operations towards the south portal, the terrain homogeneity was confirmed, allowing obtaining a very well-defined excavation section, without overhangs, leaving a front with great stability (Fig. 4).

Fig. 4. Excavation front in progress, presenting high homogeneity and good stability

The good geotechnical characteristics of the terrain, allowed obtaining RMR values of 45-50, exceeding the project estimates (Fig. 5).

The works commenced with $1 \mathrm{~m}$ passes, which could be increased up to $1.3 \mathrm{~m}$ once past the first $40 \mathrm{~m}$ of the tunnel. The advance rate stood at an average of 6 $\mathrm{m} /$ day due to the good overall performance of the tunnel.

Fig. 5. Variation of RMR values in passes 0 to the 220

The instrumentation data showed an adequate behaviour of the claystone groundmass, presenting in all sections a tendency towards stabilization (Alija 2010). Both relative measurements (strain gauge tape) and the absolute measurements in the crown (topography) showed no significant variations once the movements approached stabilisation. The lower accumulated convergence movements could be associated with reduced weathering and reduced decompression of the claystone materials.

As far as support is concerned, the initial criteria based on the use of HEB ribs and shotcrete with fibres was maintained. The use of an additional mesh 
(150x150x6 mm) to reinforce the shotcrete was considered suitable for this type of material and this procedure was considered a positive experience to be used in similar tunnels.

\section{The problem: collapse of the tunnel}

The construction works of the Ampurdán tunnel were stopped after $300 \mathrm{~m}$ of excavation due to a severe and instantaneous collapse phenomenon occurred in the first $90 \mathrm{~m}$ of the tunnel. The maximum registered deformation was located at $40 \mathrm{~m}$ from the entrance, corresponding to a downward movement of the tunnel crown and sidewalls of approximately $1.2 \mathrm{~m}$ (initial descent of $0.8 \mathrm{~m}$ and the rest during the days following the event). The deformation vanishes towards the tunnel interior and reduces toward the entrance.

The most obvious external evidence of the failure (Fig. 6 and 7) was the existence of a depression about $0.5 \mathrm{~m}$ deep at the top of the portal, over the tunnel axis, and two longitudinal fissures above the sidewalls, $30 \mathrm{~m}$ long, 0.2-0.3 m wide, and about $2 \mathrm{~m}$ deep. The surfaces of these two fissures present a subvertical arrangement with slight inclination toward the tunnel axis, extending from the surface towards the sidewalls, roughly at the level of the top heading (Fig. 6).

Fig. 6 Overview of the North portal after the collapse. The horizontal dashed line highlights the 0.5 $\mathrm{m}$ depression at the top of the portal. The dashed harrow points the downward movement. The vertical and inclined dashed lines indicate the two longitudinal fissures $30 \mathrm{~m}$ long, The circular arrow indicates the circular shape of the fissure above de tunnel lining

Another evident trace of the failure was the open fissure in the shotcrete at the portal face, immediately above the lining (Fig. 7) with the separation of the shotcrete from de ground. It could clearly be seen that part of the rockbolts were still tight to the collapsed ground and that the shotcrete partially maintained its position. 
Fig. 7. Fissure developed above the North portal lining.

The shotcrete fissure in the portal face, above the micropiles umbrella, can be interpreted as the result of the portal zone rotation, sinking more on the left side than in the right side (Fig. 6 and 7). In the tunnel interior, it was possible to appreciate the left mortar gutter totally raised by the downward movement of the sidewalls (Fig. 8).

Fig. 8 View of the provisional mortar gutter rotated upwards on the left side of the tunnel

Some cracks were also noted surrounding the area close to the portal, related to the rotation of the entire support, which despite de failure remained in good condition.

\section{Materials testing}

Aiming to understand the causes of the tunnel failure and to determine the parameters responsible for the changes in the materials properties generating the collapse, a complementary site investigation campaign was carried out, and samples were collected to use in laboratory tests. The site investigation works performed were (Fig. 9):

- 2 vertical long boreholes outside of the tunnel, from the surface until the sidewalls;

- 2 inclined short boreholes inside the tunnel in the area of the sidewalls;

- 5 test pits, separated $40 \mathrm{~m}$, inside the tunnel, next to the foundation of the steel ribs. 
Fig. 9 Layout of the complementary investigation campaign

The long boreholes intended to identify the characteristics of the material surrounding the tunnel.

The site investigation inside the tunnel intended to identify and characterize the materials distribution close to the foundation of the steel ribs and to obtain their mechanical properties. In the samples collected, the natural moisture content and deformability parameters were determined. In particular, $3 \mathrm{CU}$ triaxial tests, $2 \mathrm{CU}$ direct shear tests, 6 UU direct shear tests and 21 moisture content tests were carried out. The boreholes inside the tunnel showed the presence of about $30 \mathrm{~cm}$ composed of brown sandy silt, saturated with water and presenting a high degree of de-structuring and weathering. The samples of this level had an average natural water content of $28 \%$. Below this first level, the same material was less weathered, with an average natural water content of $21 \%$. The outside boreholes detected an increase in the water content at the height of the foundation of the ribs, with an average value of $20 \%$.

The direct shear tests and the triaxial tests executed on 11 intact samples, gave similar results to those obtained in the initial geotechnical characterization.

Only after evaluating the results of the boreholes, it was decided to dig the five test pits with two purposes: to verify the spatial distribution of the weathered claystone and to obtain large size undisturbed claystone samples to study their weatherability in presence of water. Once the weatherability was analysed, the intention was to test the samples in weathered conditions as close as possible to the parameters at the time of failure.

The test pits showed a weathered thickness of approximately 0.3 m easy to dig. Below this level, it was easy to dig up to $0.5 \mathrm{~m}$, but below that depth, it became difficult to excavate using mechanical equipment. One day later the test pits began to seep water and finally become totally clogged.

The information obtained allowed to infer that the deformation stopped at a depth where the support reached unweathered material (Plaza Castel 2008).

For the study of the claystone decay, 4 samples were collected inside the Ampurdán tunnel, in its central part, during the advance phase. The samples were 
the deepest possible to ensure unweathered conditions. The samples were tightly packed in hard plastic bags, labelled and immediately transported to an accredited laboratory. The tests conducted on these samples were: natural moisture content, grain size analysis, Atterberg limits, Slake Durability Test (Franklin \& Chandra 1972) and the Jar Slake Test of Lutton (Mohamad et al. 2011). All the samples showed a high content of fine particles, above $90 \%$. The samples were classified as CL considering the unified soil classification system. The natural moisture content of the samples collected in the pits ranged from $21.9 \%$ to $24.4 \%$. The plasticity values obtained were since $22.8 \%$ to $24.7 \%$, being above the values obtained in previous tests (18\%). Based on the plasticity index, the samples were classified as highly plastic soils (>15\%). The liquid limit was between $32.8 \%$ and $49.5 \%$.

In relation to the samples used in the Slake Durability Test, the average result for the first cycle was $12 \%$, while $0 \%$ was obtained in the second cycle. This indicates that the claystone is extremely weatherable in the presence of water, degrading completely during the test, and therefore the slake durability test is not suitable for this type of very sensitive claystone material. After the results obtained in the previous test, the samples were submitted to the Jar Slake test, less aggressive than the slake durability test, where the samples are only submitted to cycles of wetting and drying. The result showed that all the samples, within $24 \mathrm{~h}$ of being submerged in water became a mud (Gómez Ramírez 2006).

Another part of the analysis focused on the information provided by the instrumentation before and after the tunnel collapse. From a detailed study of the pre-failure information, it was concluded that based on the available data, the failure couldn't be anticipated. The behaviour of the tunnel was good, with the convergence plots showing a clear tendency towards stabilization, without any significant variations once stabilised.

One day after the failure, a continuous topographic monitoring of the crown and sidewalls was started, together with the installation of entire sections and additional auscultation devices in the tunnel and slopes, allowing a precise control of the tunnel's deformations. The evolution of the absolute movements of the tunnel crown, before and after the failure are presented in Fig. 10. 
Considering the convergence evolution of the section presenting the largest vertical movement, convergence $\mathrm{C}-5$, the following interpretation could be inferred (Alija 2010):

- The greatest vertical movement occurred at the moment of the collapse, and was around $80 \mathrm{~cm}$;

- Following the collapse, the crown entered in a second phase of displacement, dropping $40 \mathrm{~cm}$ in 7 days, equivalent to a speed of about 6 cm per day;

- In a third and final phase of movement, the crown reduced its displacement until a very low rate, dropping only $1 \mathrm{~cm}$ in 29 days. The convergence graphs showed an "asymptotic" trend until complete stabilization 36 days after the failure.

Fig. 10 Evolution of the absolute movements of the tunnel crown before and after the failure.

\footnotetext{
Based on the evaluation and interpretation of all the information previously presented, the failure mechanism of the Ampurdán tunnel can be explained as follows:
}

- During the advance of the tunnel, some stress release had occurred around the excavation, inducing volume changes, decompression and the increasing of the water content of the claystone.

- In the north portal the groundmass foundation the lining become embedded in water, drained through the sandstone layers and recharged by circulation in the claystone fissures of the Ampurdán formation. The increase in the moisture content easily surpassed the plastic limit of the clays and therefore changed the geomechanical behaviour of the claystone in the foundation of the lining.

- The failure is attributed to the collapse of the foundation material after the water content increase, which significantly reduced the bearing capacity of the claystone. A generalized plasticization of the clays induced a strength loss and the shear failure of the ground at the ribs foundation level. 
- The mineralogy of the clays, the degree of cementation and the microtexture could also had influenced the increase of the water absorption, and reduced the geomechanical behaviour of the claystone.

\section{Finite element simulation}

After the complementary site investigation, the sampling of the in situ materials and the evaluation of the instrumentation data, it was considered necessary to determine the changes in the geomechanical properties of the materials around the tunnel lining that caused the collapse.

In order to simulate the failure conditions, several attempts were made to run tests under conditions similar to those responsible for the failure, but due to the high weatherability of the claystone, the samples disintegrated in the presence of water, preventing the execution of the tests. Faced with the impossibility to do reliable laboratory tests, it was decided to use of a finite element model program to do a parametric study and thus to determine the evolution of the geotechnical parameters during the claystone weathering process. The stresses and strains induced by the excavation, as well as the identification of the variables that may had greater incidence in their development, could be inferred by the finite element model. The determination of the geotechnical parameters dependent on weathering is also vital for a suitable design of the construction procedures and the support solutions.

To compute the tunnel's elastoplasticity a numerical simulation was used. The models were computed using the finite element method based on the bidimensional PLAXIS software of the company PLAXIS B.V, considering the ground as a continuum space (Brinkgreve 2004). Finite element models can be plane strain or axisymmetric. In this case, since it could be assumed a uniform cross section, having uniform stress conditions and loads along the tunnel (direction z), flat deformation models (plane strain) were considered. Triangular elements of 15 nodes were used to model the tunnel, providing a fourth order interpolation for the displacements, and the numerical integration embrace twelve Gauss points (evaluation stress points). 
For the support, a combined rigidity to flexion EI and the resistance to axial stress EA was used. From these two parameters, an equivalent plate thickness was used. The NATM was considered, taking into account the existence of a lining composed of plates and an interface on the outside. The tunnel outline consisted of arch shaped sections.

For the calculation, a mechanical Mohr-Coulomb constitutive model was initially considered, in order to deal with the same assumptions as those used during the construction works. To use this model, it was also taken into account that the collapse phenomenon occurred suddenly, and that on the days prior to failure no convergence movements have been detected, nor absolute movements in the crown.

However, based on previous experience of other works with Plaxis, it is known that with the Mohr-Coulomb model the same module is taken to load and discharge, resulting in an excessive lifting of the ground (this situation was proved with the numerical model). For this reason, the model that has been considered was the Hardening Soil (Xu \& Wang 2002), which assumes that the discharge module is 3 times higher than the loading module. This model yielded more realistic results for the present case study, and the deformation values were closer to those actually obtained in the auscultation sections. The Hardening Soil model is a variant of the hyperbolic model, formulated within the plasticity hardening by friction. This model is suitable for the simulation of the behaviour of soft sediments and clay soils. In contrast to a perfect elastoplastic model, in the Hardening Soil, the creep surface is not fixed in the space of the main stresses, since it can be expanded due to plastic deformations.

The study of the tunnel's behaviour related to the variation of these properties was the basis for the parametric study to determine the causes of the tunnel failure. The geotechnical parameters initially used in the calculation for the materials crossed by the Ampurdán tunnel are presented in Table 3.

Table 3 Initial pre-failure parameters considered in the calculations 
As section C-5 presented the largest deformation when the tunnel collapsed, it $30 \mathrm{~m}$. The support parameters for the modelling have been adapted according to those corresponding to section type S-III. The advance line was considered at a height of $6.0 \mathrm{~m}$ being the excavation and support phases analysed according to the implementation of the works: top heading advance in one phase with $1 \mathrm{~m}$ passes, and bench demolition in two phases with 2 m passes.

The complete calculation sequence of excavation and support for the Ampurdán tunnel was composed of the following phases:

Phase 0 . Initialization of the model.

Phase 1. Excavation of the top heading.

Phase 2. Support of the top heading.

Phase 3. Excavation of the left bench.

Phase 4. Support of the left bench.

Phase 5. Excavation of the right bench.

Phase 6. Support of the right bench.

\section{Results and discussions}

Once the model was set to the initial situation, a parametric study was undertaken, reducing the values of the materials properties, until obtaining $80 \mathrm{~cm}$ of subsidence in section $\mathrm{C}-5$. The variations of the geotechnical parameters due to the presence of water that affected the materials in which the tunnel was excavated were also studied. The reduction of the parameters for analysis was carried out by percentages of reduction. As a working assumption, it was considered that the percentage reductions should not affect equally all the parameters analysed. To carry out the study as closely as possible to the actual conditions, typical values currently used for clays, with different degrees of consistency were taken into account (Ministerio de Fomento 2008).

The first step consisted in the verification of the model in the initial unchanged situation. This analysis was named: Study 1 Initial Situation, and the 
corresponding results of the presumed strain and stress were obtained for the top heading advance phase. However, in phase 5 of Study 1, excavation of the right bench, the strain on the left wall reached $71 \mathrm{~mm}$, and the crown reached $36 \mathrm{~mm}$ (Fig. 11). For the initial situation, the calculation of the stable phase 6 was not achieved since the tunnel destabilized.

Fig. 11 Schematic by arrows of total displacements at the end of phase 5 for Study 1

This situation that did not correspond to the behaviour of the tunnel required the reformulation of the values assigned to the Ampurdán claystone. The values considered were based on laboratory tests for the strength parameters, and on "in situ" tests for the deformation parameters. Considering the high weatherability of these materials, it seems reasonable to believe that during the execution of the boreholes the samples could had been weathered, causing a significant reduction in strength values. On the other hand, it is important to highlight that preconsolidated sediments typically present a decrease in strength values obtained in the laboratory, in respect to natural conditions, since rupture occurs by previous fissures developed during decompression, while collecting the sample (González de Vallejo et al. 2002). The good stability of the tunnel during construction is also evidence that the strength parameters considered in Study 1, were lower than the real ones. The good results of the auscultation campaign and the RMR values in the excavation face also supported that idea.

Based on the previous assumptions, it was concluded that the values for the Young modulus obtained in the pressuremeter tests could be closer to the real values of the material under natural conditions. Thus, taking into account the routine geotechnical correlations used in the study phases, it could be considered that for a deformation modulus of $200 \mathrm{MPa}$, a value of $100 \mathrm{kPa}$ for the effective cohesion and of $35^{\circ}$ for the effective friction angle could be acceptable (Jiménez Salas et al. 1976; Justo Alpañes 1968). A new modelling study (Study 2: Modified Initial Situation) was undertaken using these last parameters. In this study, phase 6 of support of the right bench can be reached with acceptable results of $10 \mathrm{~mm}$ 
maximum accumulated displacement in the sidewalls, and $14 \mathrm{~mm}$ in the crown. Once the initial situation model was determined to correspond to the real conditions of the tunnel before the subsidence processes, the reduction in the geotechnical characteristics of the materials that gave rise to the tunnel subsidence was done. The parameters considered the most relevant, are the following:

- Secant elastic modulus: $\mathrm{E}_{50}$

- Effective cohesion: c'

- Internal friction angle: $\quad \phi$

- Apparent density: $\quad \rho$

The reductions proposed for the consecutive parametric studies considered is presented in Table 4.

Table 4 Values considered for the parametric study and sequential reduction for each parameter

The displacements computed at the end of Study 3, were similar to those of Study 2 , with a slight increment. In this case, the displacement in the crown reached 15 $\mathrm{mm}$ towards the tunnel interior. The ground reached $14 \mathrm{~mm}$ and the radial deformations up to $11 \mathrm{~mm}$ (Table 5).

Table 5 Accumulated deformation in the crown for the studies performed

For Study 6 (Fig. 12) the acceptable parameters were considered those of a cohesive soil of hard or rigid consistency. This study showed a significant increase in the deformations at the end of stage 6 as compared to the previous ones. Thus, from the $22 \mathrm{~mm}$ in the crown for Study 5, in study 6, $32 \mathrm{~mm}$ were reached (Table 5). In the floor, there was an uplift increment of $13 \mathrm{~mm}$ from Study $5(23 \mathrm{~mm})$ to Study $6(36 \mathrm{~mm})$. The differences between the radial 
deformations of both sidewalls are accentuated in this study, reaching up to 45 $\mathrm{mm}$ on the left and $32 \mathrm{~mm}$ on the right.

Fig. 12 Total displacements produced at the end of phase 6 in study 6

In Study 9, the reduction in the ground parameters lead to the failure of the tunnel in the bench excavation phase. At the end of phase 2 (support in top heading) the deformations surrounding the tunnel were very high, particularly in the floor, next to the sidewalls, reaching deformations around $260 \mathrm{~mm}$.

Considering values representative of a cohesive material of soft consistency, that were used in Study 10, the excavation of the top heading (phase 1) is close to failure. The floor deforms $95 \mathrm{~mm}$ into the tunnel, while the crown drops about 20 $\mathrm{mm}$. During the support of the top heading, the tunnel collapse was produced. Figure 13 presents the deformations towards the interior of the tunnel, reaching $800 \mathrm{~mm}$ in the crown, and in the floor in the foundation area of the ribs, reached $1430 \mathrm{~mm}$.

Fig. 13 Diagram of total displacements produced up to failure in phase 2 of Study 10

A summary of the accumulated values obtained for the crown deformation in the Studies 2 to 10 , is presented in the Table 5 .

In Table 5 and in Fig. 14 it is evident how the deformations increment are low until Study 5, with an almost linear tendency in the six phases of excavation and support. In Study 5, the deformations in the crown slightly increase after the support phase of the left blasting (phase 4). After Study 6, the deformations dramatically increase, reaching destabilization during the bench excavation, in Studies 8 and 9. In Study 10, the excavation phase is still stable, but the failure arises during the support phase. 
Fig. 14 Evolution of displacements in the crown for each study, by phases

Considering the parametric study performed, it can be stated that the parameters of Study 10 are representative of the material of Ampurdán Claystone Formation $\left(\mathrm{M}_{\mathrm{A}}\right)$ in weathered conditions, as they allowed reproducing the deformations measured in situ after the tunnel failure. These parameters are summarized in Table 6 .

Table 6 Comparison between assumed intact parameters and computed parameters at failure of Ampurdán claystone Formation $\mathrm{M}_{\mathrm{A}}$

Comparing the values presented in Table 6, considered representative of the in situ materials properties at the time of the tunnel failure (Study 10), with the intact pre-failure parameters assumed in the finite element simulation (Study 2), they correspond to reduce the initial values to $69 \%$ in the apparent density and in the effective friction angle, to $12 \%$ in effective cohesion and to $4 \%$ in the Young modulus.

\section{Conclusions and recommendations}

The abundance of water in the groundmass of the Ampurdán tunnel allowed the weathering of the mudstone softrocks on which the tunnel support relies, reducing their geotechnical properties, and causing the tunnel failure.

The fact that the usual monitoring indicators used to evaluate the behaviour of the tunnel, did not gave warning about the failure that subsequently occurred, highlight the importance of using preventive procedures in the tunnels excavated in similar softrock materials. Therefore, the evolution and quantification of the geomechanical properties of softrocks, when subjected to excavation, decompression, and exposure to water, is of particular importance to determine the actions to be taken during the tunnel's construction. 
The support procedure installed in the tunnel appeared to be suitable for the initial groundmass materials degraded. The weatherability tests showed that due to the presence of water, a support suitable for a terrain of medium-soft consistency should have been used.

Special attention should be given to the process of defining the geotechnical parameters in softrocks, requiring a depth study for a correct understanding of their behaviour. They are materials that in unaltered conditions present good geotechnical behaviour, facilitating the excavation of the tunnel, but when weathered, because of unloading and wetting, may suffer important loss in strength.

When a tunnel is to be built in softrocks, during the design it is necessary to define adequate construction and supervision methods, adjusted to the most unfavourable conditions. The contemporary modelling tools using finite elements are especially useful, allowing the simulation of the behaviour of the structure whilst adjusting the geotechnical characteristics of the groundmass material. The parametric study performed in the present case study allowed to simulate the deformations measured in situ after the tunnel failure. The final results of the finite element modelling were considered representative of the material of the Ampurdán claystone Formation $\left(\mathrm{M}_{\mathrm{A}}\right)$ in weathered conditions. All the parameters at failure are worse than those of intact situation, corresponding to a wide range of reductions to $69 \%$ of the original effective friction angle and the apparent density, to $12 \%$ of the effective cohesion, and only to $4 \%$ of the initial Young modulus. This example stresses the fact that a detailed study must be done for each tunnel geometry and groundmass material in order to reach suitable behaviour characterization and adequate construction solutions.

The experience obtained during the construction of the tunnel in the claystone materials, allowed proving that the finite element method is a suitable "tools" to adjust the design, helping to minimize the number of incidents during the excavation and support works for tunnels built in similar materials. 
Acknowledgments This work was funded by the Portuguese Government through

FCT - Fundação para a Ciência e a Tecnologia under the project PEst-

OE/CTE/UI0073/2011 of the Geosciences Center.

\section{References}

Agustí J, Berástegui X, Llenas M, Losantos M, Mató E, Picart J, Saula E (1994)

Evolución Geodinámica de la Fosa del Emporda y las Sierras Transversales. Acta Geológica Hispánica 29(2-4): 55-75 (Pub 1996) (in Spanish)

Alija S (2010) Análisis retrospectivo sobre la problemática de túneles ejecutados en rocas blandas. Tesis doctoral. Departamento de Ingeniería del Terreno.

Universidad Politécnica de Valencia. Valencia, España (in Spanish)

Barton N (2000) El sistema Q para la selección de sostenimiento con el Método

noruego de excavación de túneles. Ingeotúneles vol 3. Ed López Jimeno, Madrid (in Spanish)

Bieniawski ZT (1989) Engineering Rock Mass Classifications. A WileyInterscience, USA

Brinkgreve RJ (2004) PLAXIS V8 Manual de Referencia (in Spanish)

Cornejo Álvarez L (1988) Excavación Mecánica de Túneles. Ed Rueda, Madrid (in Spanish)

Díaz Méndez B (1997) Clasificación de los Terrenos según su Excavabilidad. In: López Jimeno C (ed) Manual de Túneles y Obras Subterráneas Ch 5: 183-211. Entorno Gráfico SL, Madrid (in Spanish)

Franklin JA, Chandra R (1972) The slake-durability test. International Journal of Rock Mechanics and Mining Sciences \& Geomechanics Abstracts 9(3): 325-328

Gómez Ramírez S (2006) Efecto de los Cambios de Succión y Tensión en la Degradación de Argillitas. Tesina Final de Carrea UPC, Barcelona. 113 p (in Spanish)

González de Vallejo LI, Ferrer M, Ortuño L, Oteo C (2002) Ingeniería Geológica. Pearson Educación, Madrid (in Spanish) 
Hoek E (1998) Tunnel support in weak rock. Keynote address Symposium of

Sedimentary Rock Engineering. Taipei, Taiwan, $13 \mathrm{p}$

Hoek E, Brown ET (1985) Excavaciones Subterráneas en Roca. Mc Graw Hill, USA

Hoek E, Brown ET (1988) The Hoek-Brown Failure Criterion - a 1988 update. Proc $15^{\text {th }}$ Canadian Rock Mech Symp. Dep. Civil Engineering, University of Toronto, Toronto, pp 31-38

IGME (1995) Mapa Geológico de España. Escala 1:50.000. Hoja 295 "Banyoles". Madrid (in Spanish)

Jiménez Salas JA, Justo Alpañes JL, Serrano A (1976) Geotecnia y Cimientos II. Mecánica del suelo y de las rocas. Ed Rueda, Madrid (in Spanish)

Justo Alpañes JL (1968) Medida de Presiones Intersticiales y de Deformaciones "In Situ”. Simposio sobre Ensayos Geotécnicos in Situ. Lab Transp, Madrid (in Spanish)

López Jimeno C (1996) Manual de Túneles y Obras Subterráneas. Ed Entorno Gráfico, Madrid (in Spanish)

Ministerio de Fomento (2008) Recomendaciones Geotécnicas para Obras Marítimas y Portuarias. Capítulo II, Investigación Geotécnica. Puertos del Estado (in Spanish)

Mohamad ET, Saad R, Abad SK (2011) Durability assessment of weak rock by using jar slaking test. Electronic Journal of Geotechnical Engineering 16(0): 1319-1335

Plaza Castel A (2008) Análisis del Comportamiento de un Túnel Excavado en Rocas Altamente Expansivas. Tesina UPC, 160 p (in Spanish)

Romana Ruiz M (1997) Apuntes de Túneles de Carreteras. Ed Escuela de Camino (in Spanish)

Wang Z, Wong RK, Li S, Qiao L (2012) Finite element analysis of long-term surface settlement above a shallow tunnel in soft ground. Tunnelling and Underground Space Technology 30: 85-92 
Xu Z-H, Wang W-D (2002) Selection of soil constitutive models for numerical analysis of deep excavations in close proximity to sensitive properties.

Department of Underground Structure \& Geotechnical Engineering East China 


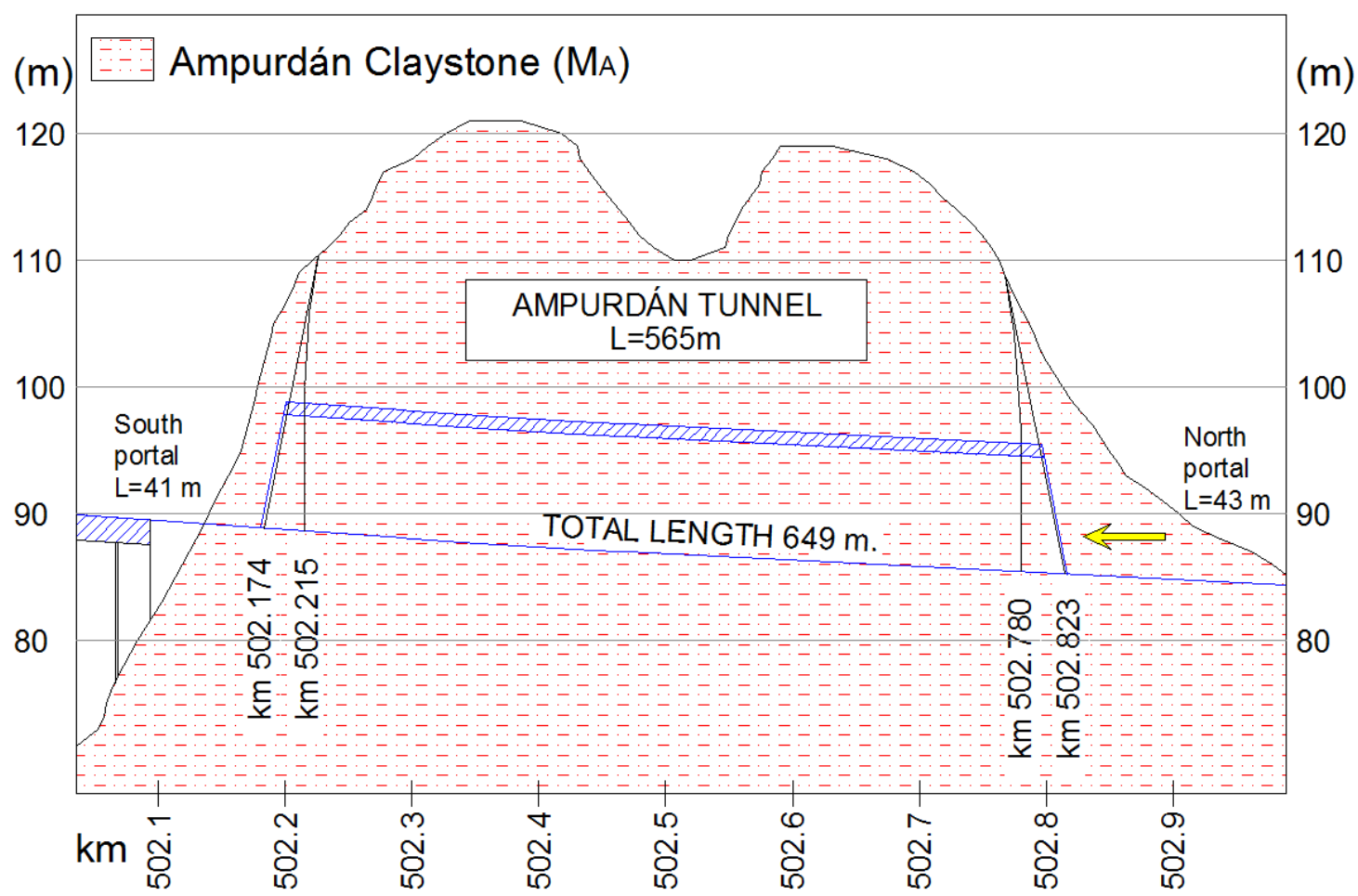

Fig. 1 Profile of the Ampurdán tunnel. The arrow points the advance direction

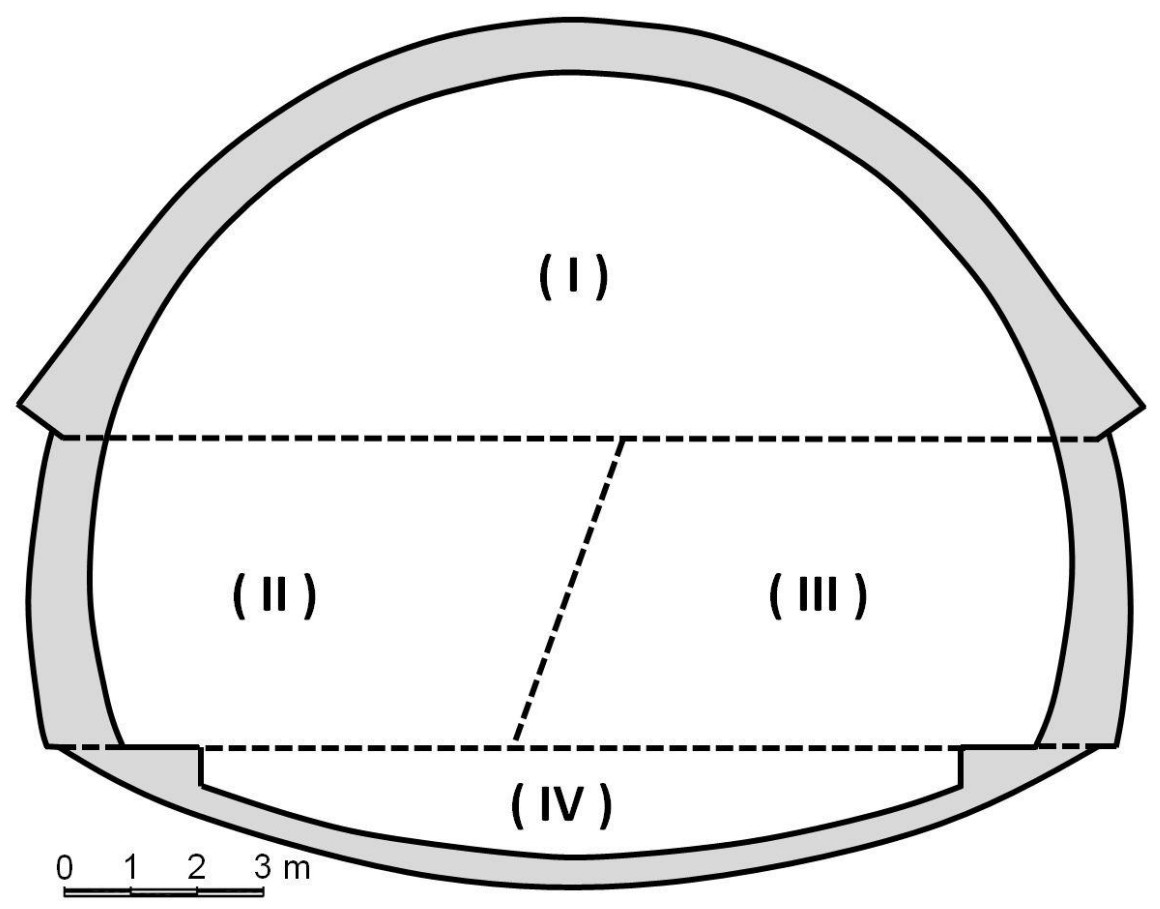

Fig. 2 Cross-section of the tunnel with elephant's foot. I - top heading, II and III - bench, IV invert 


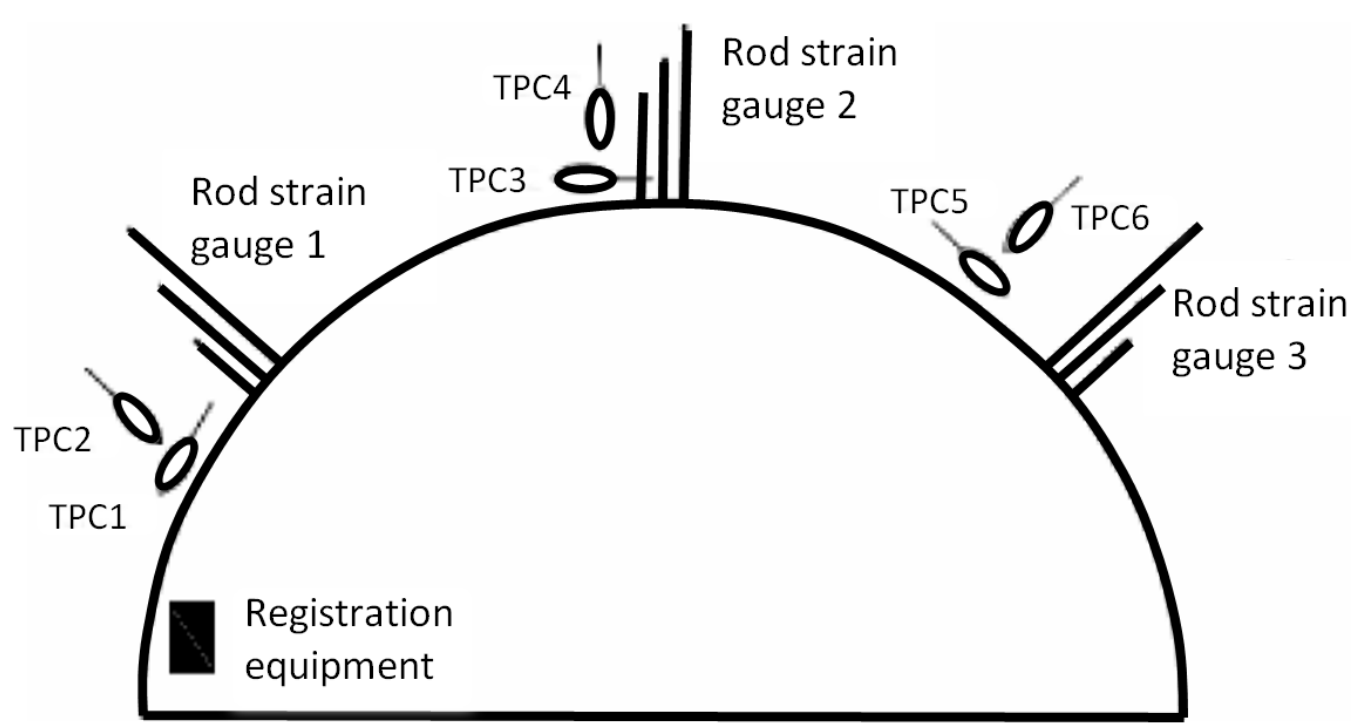

Fig. 3. Sketch of the cross-section monitoring arrangement. TPC - total pressure cell.

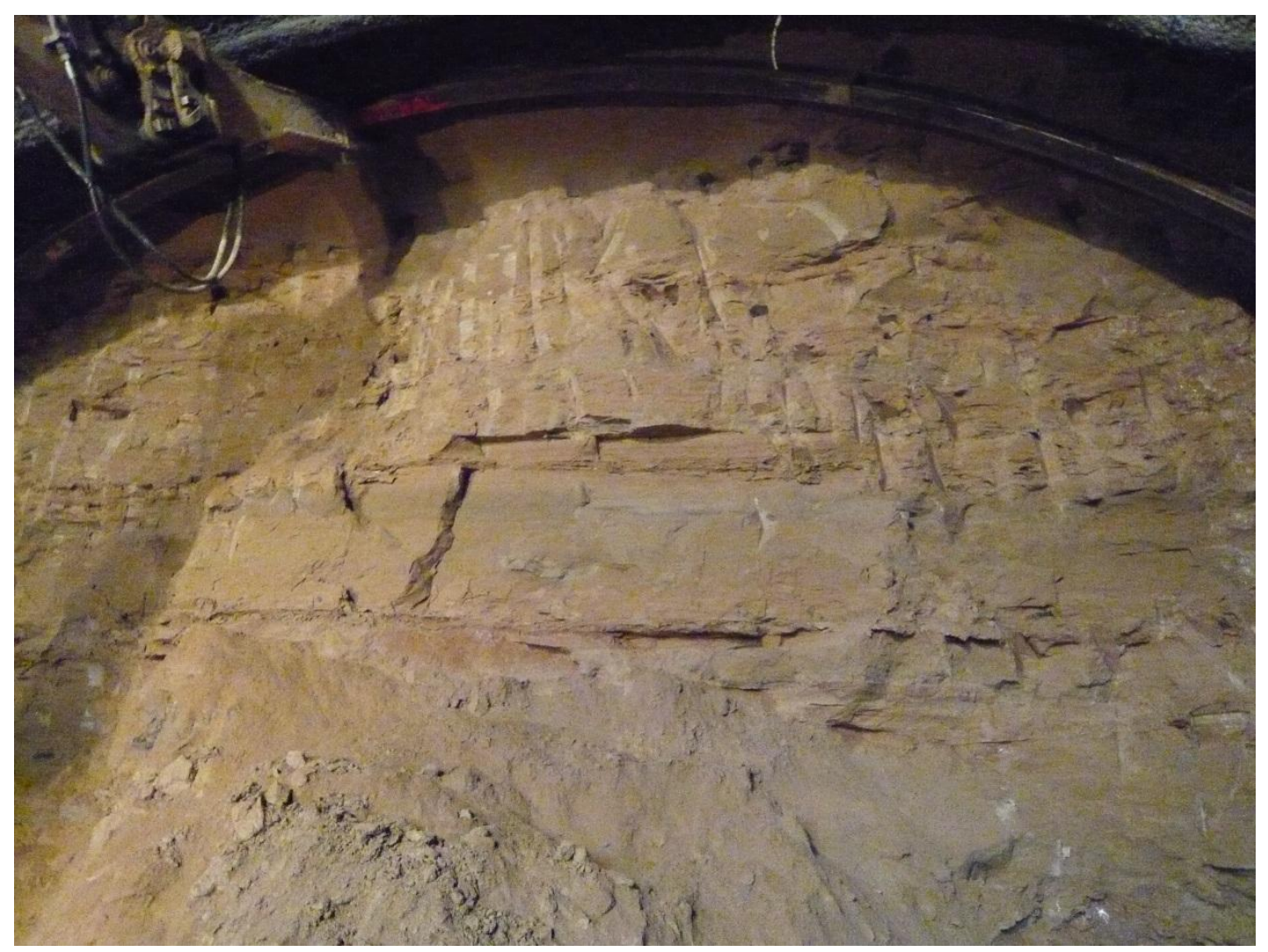

Fig. 4. Excavation front in progress, presenting high homogeneity and good stability 


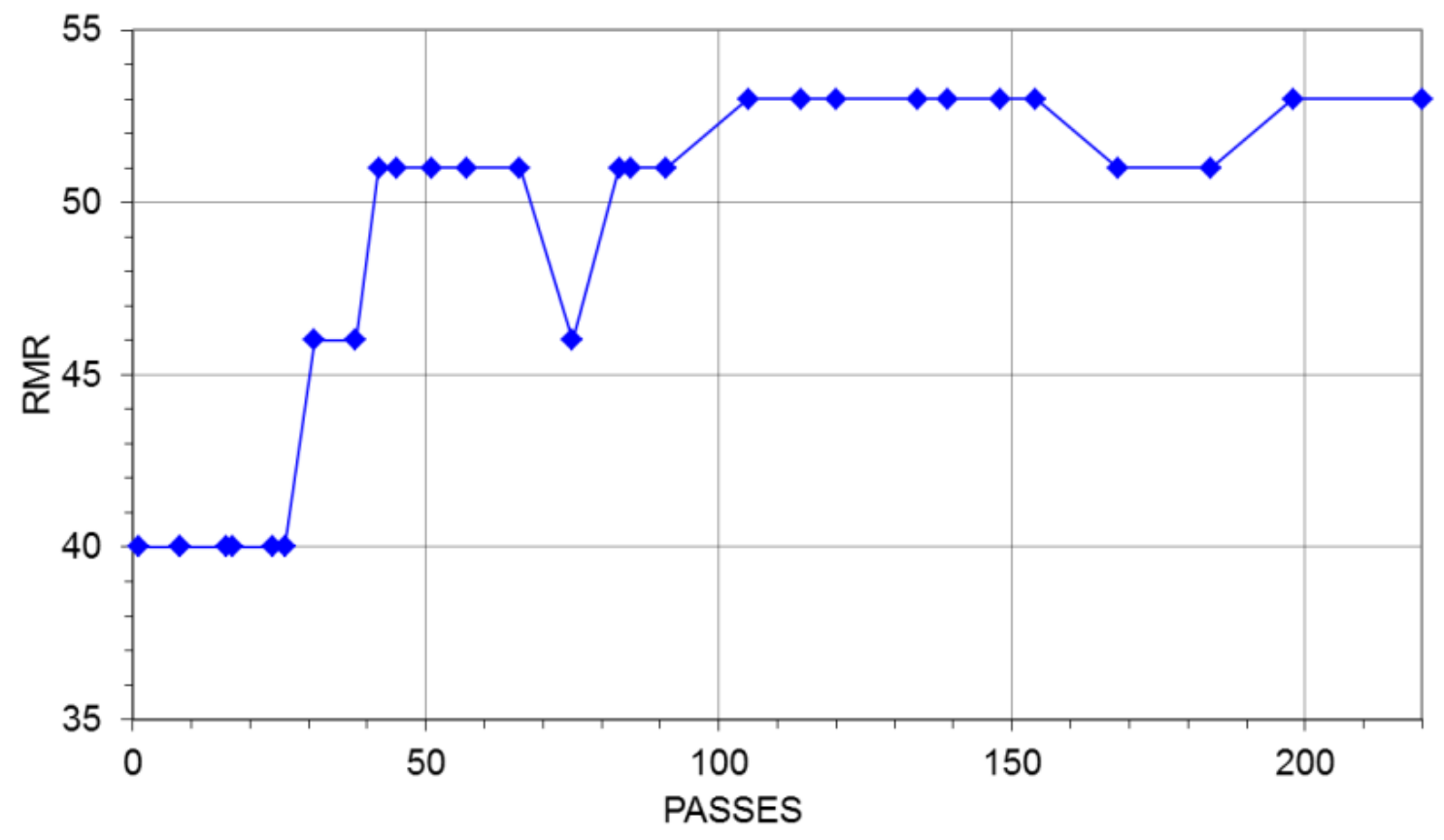

Fig. 5. Variation of RMR values in passes 0 to the 220 


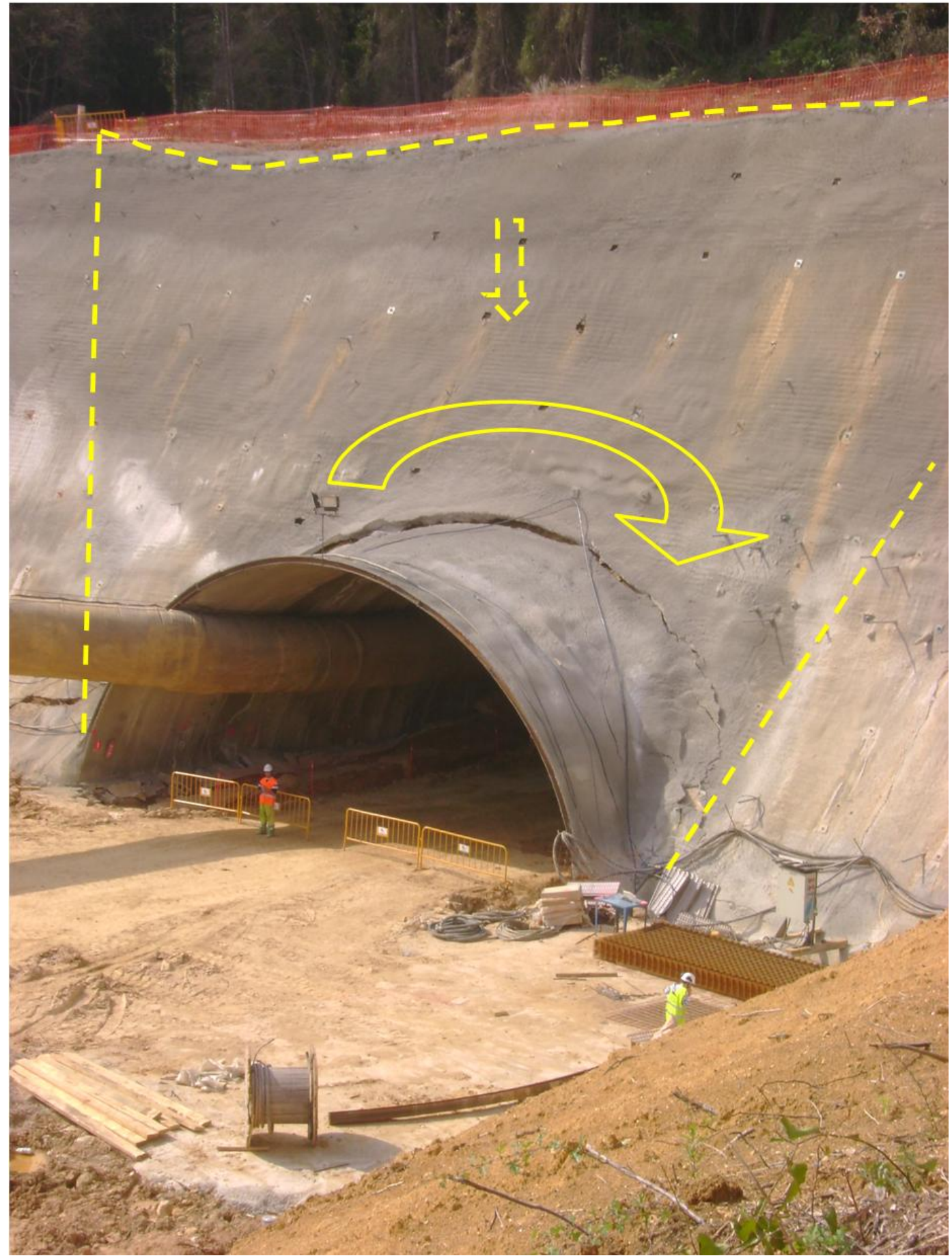

Fig. 6 Overview of the North portal after the collapse. The horizontal dashed line highlights the 0.5 $\mathrm{m}$ depression at the top of the portal. The dashed harrow points the downward movement. The vertical and inclined dashed lines indicate the two longitudinal fissures $30 \mathrm{~m}$ long. The circular arrow indicates the circular shape of the fissure above de tunnel lining 


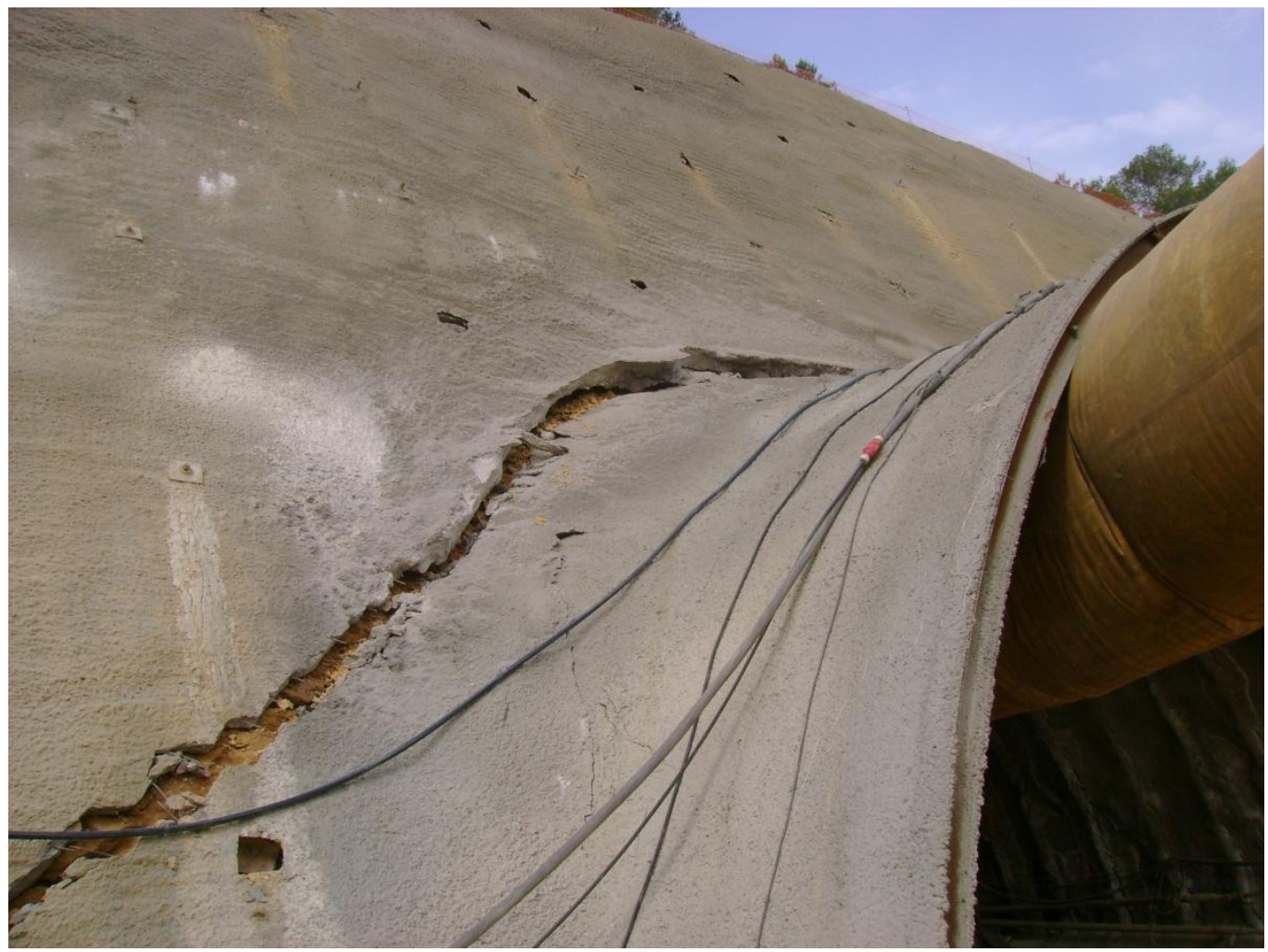

Fig. 7. Fissure developed above the North portal lining.

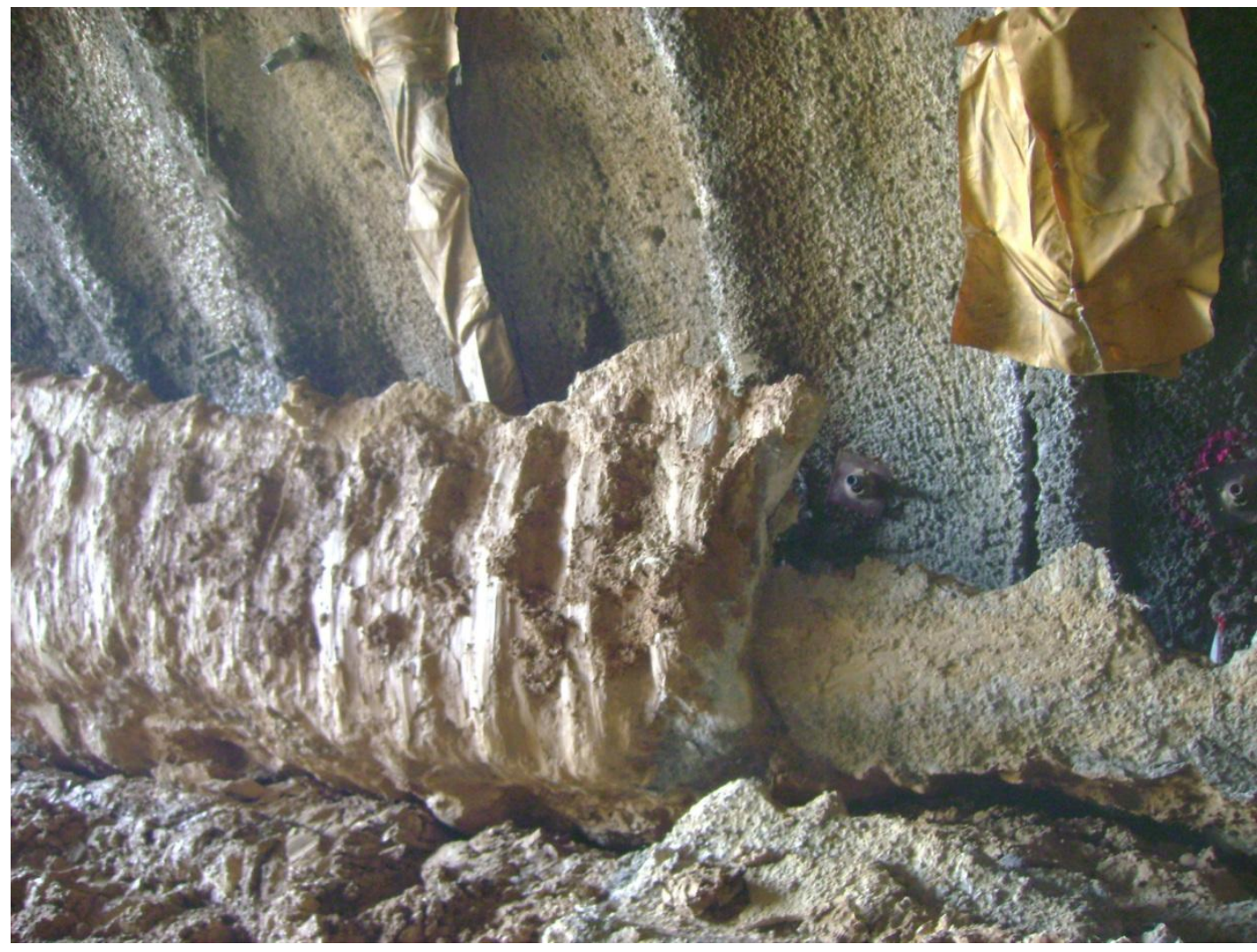

Fig. 8 View of the provisional mortar gutter rotated upwards on the left side of the tunnel 
Fig. 9 Layout of the complementary investigation campaign

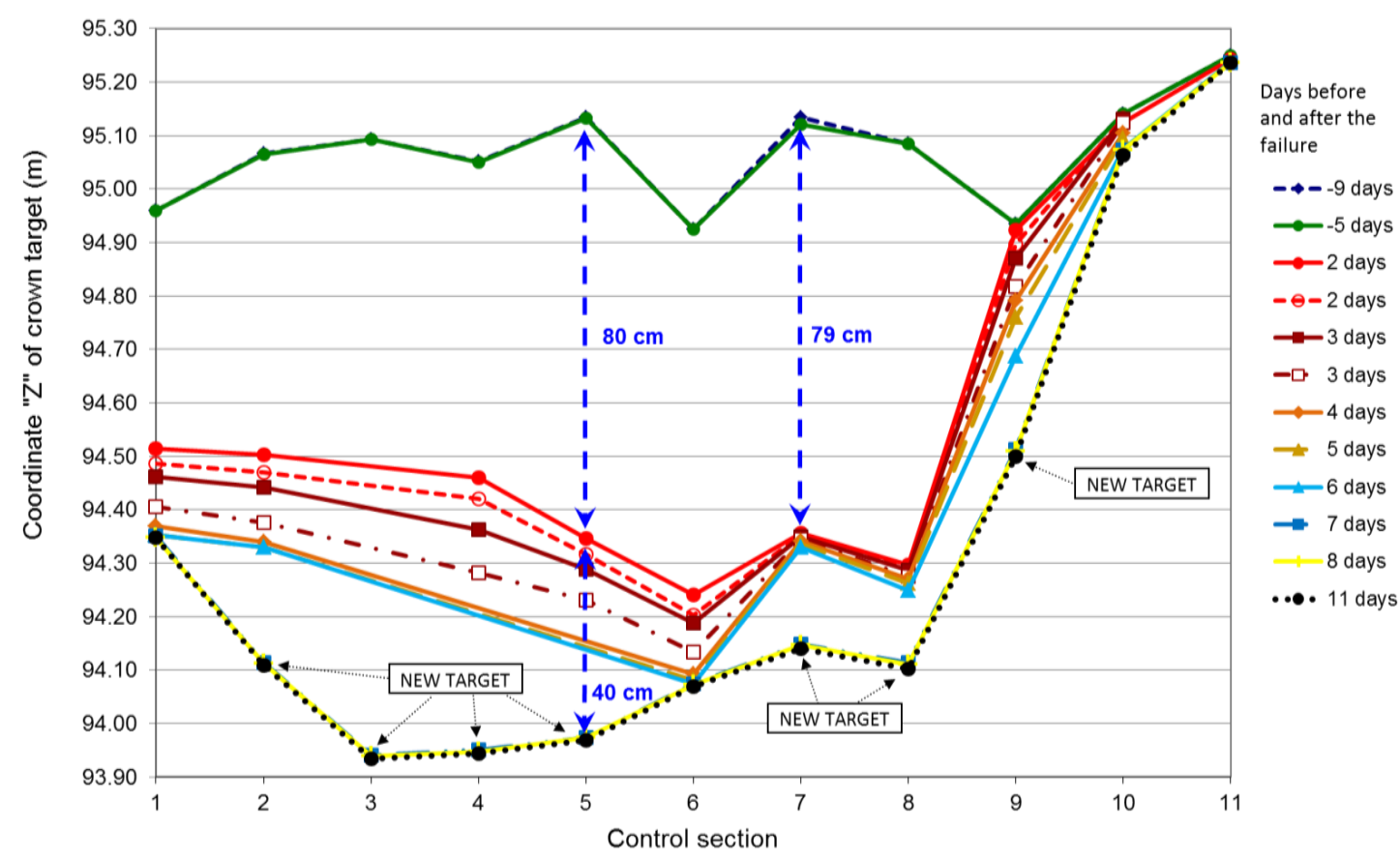

Fig. 10 Evolution of the absolute movements of the tunnel crown before and after the failure 


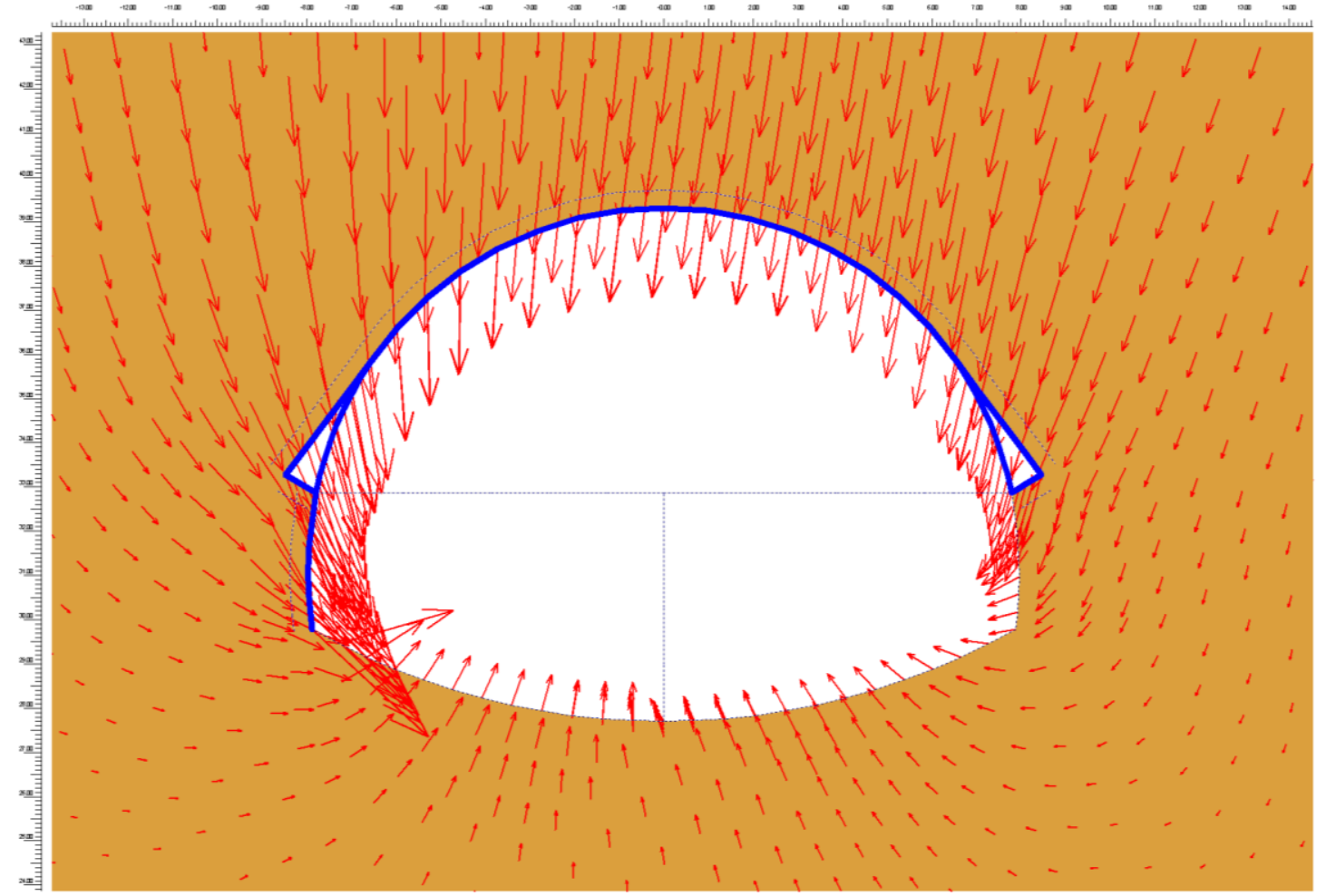

Fig. 11 Schematic by arrows of total displacements at the end of phase 5 for Study 1

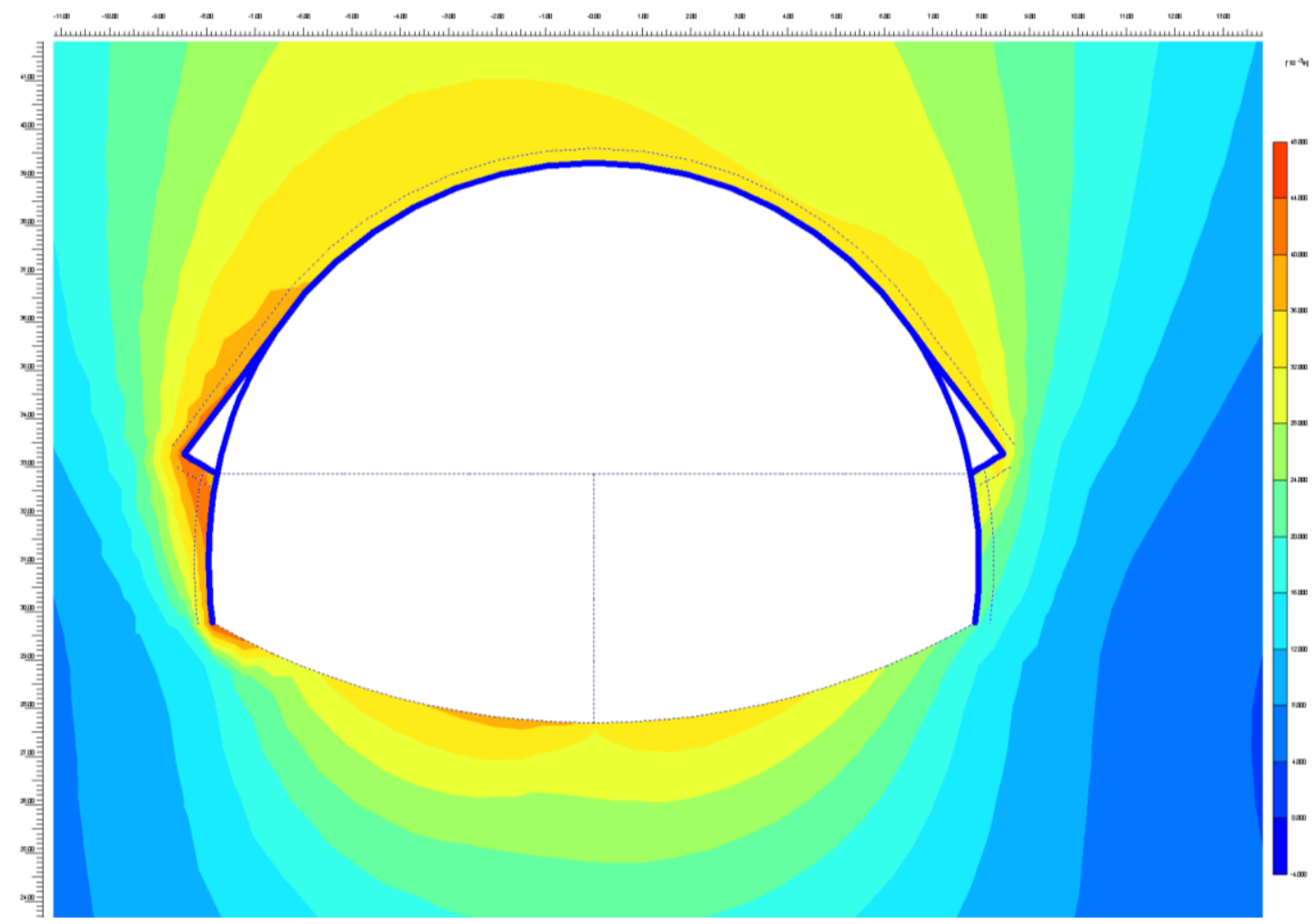

Fig. 12 Total displacements produced at the end of phase 6 in study 6 


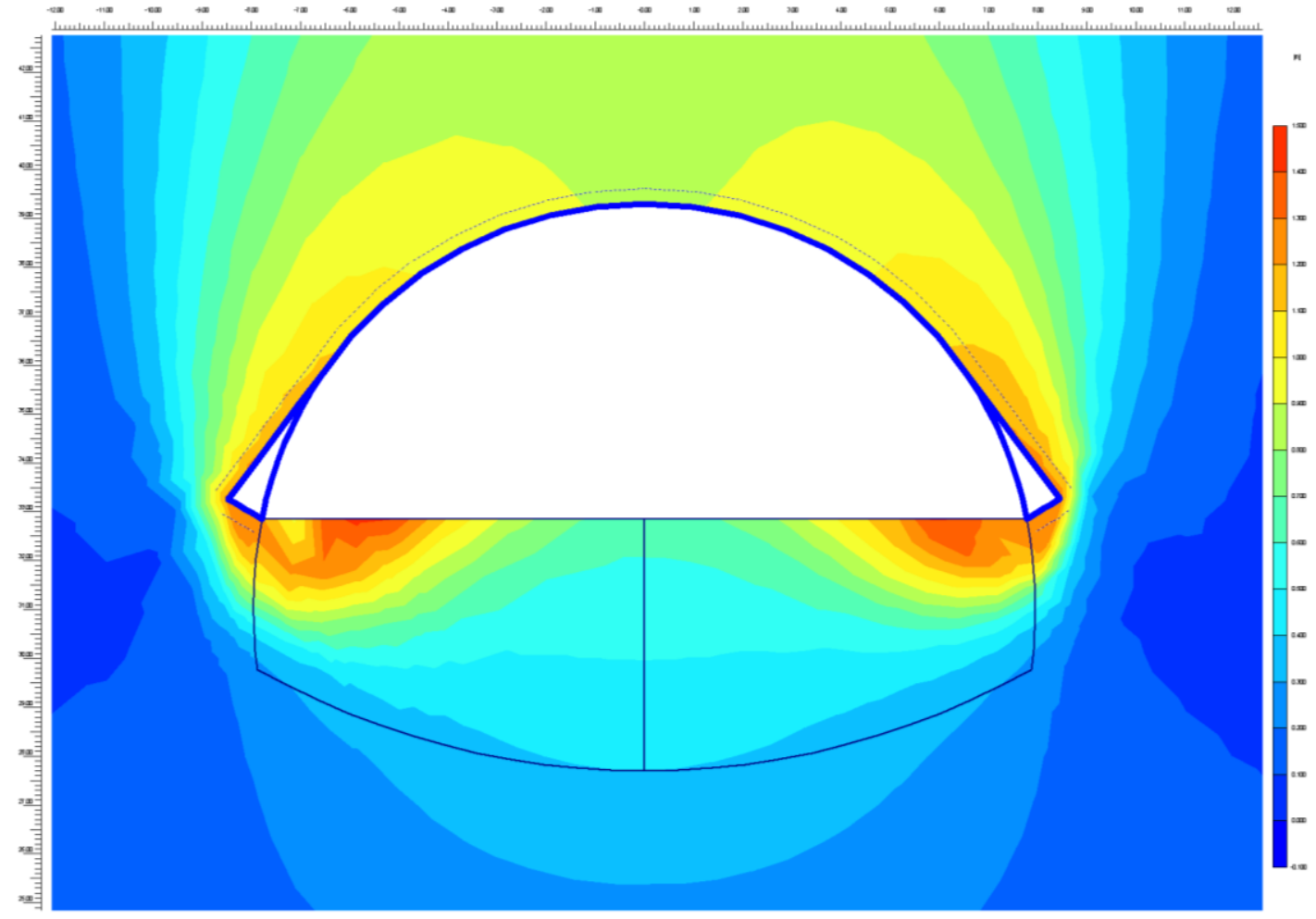

Fig. 13 Diagram of total displacements produced up to failure in phase 2 of Study 10

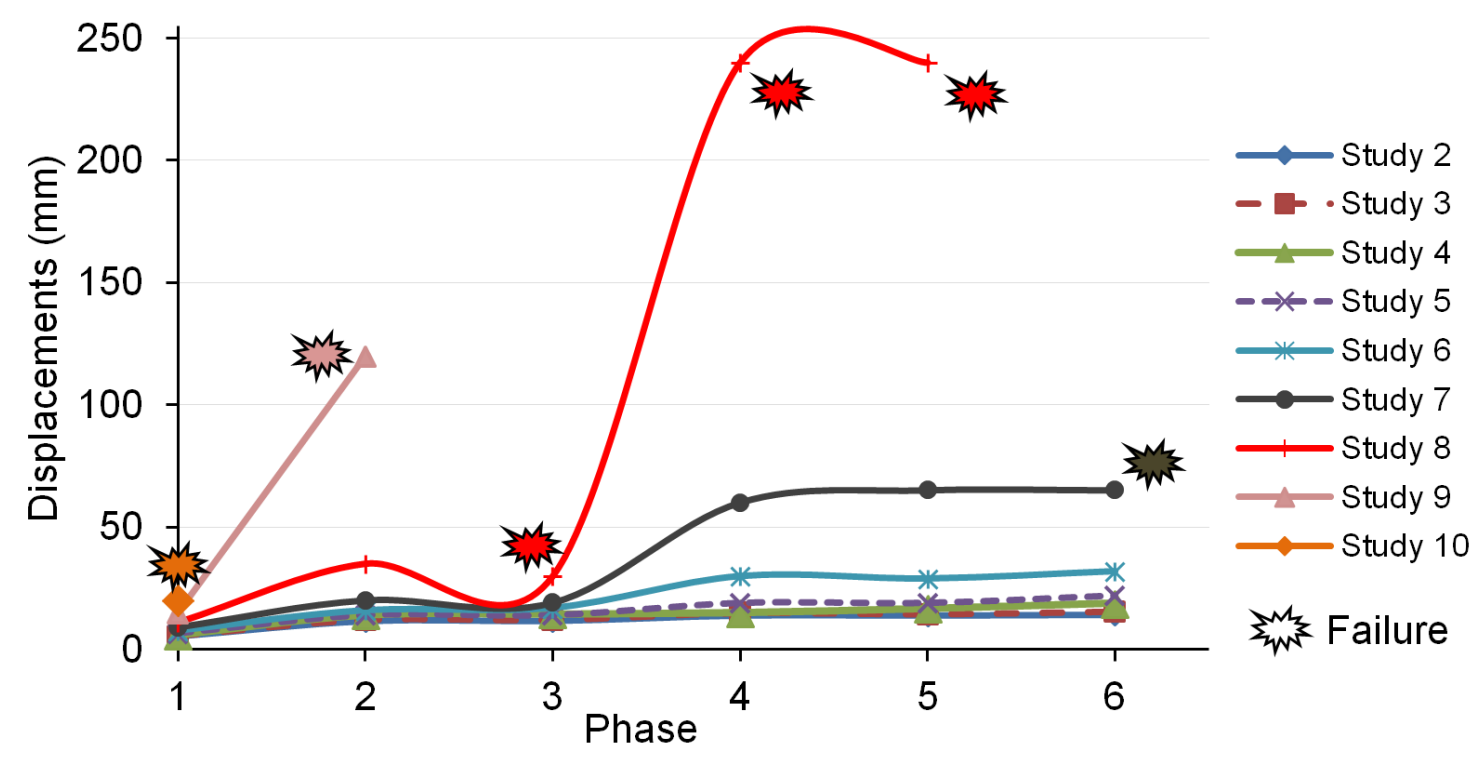

Fig. 14 Evolution of displacements in the crown for each study, by phases 


\section{TABLES}

Table 1 Summary of the geotechnical parameters considered in the design of the Ampurdán tunnel

\begin{tabular}{|c|c|c|c|c|c|c|c|}
\hline \multirow[t]{2}{*}{ Formation } & $\begin{array}{c}\text { Apparent } \\
\text { density }\end{array}$ & $\begin{array}{l}\text { Uniaxial } \\
\text { compressive } \\
\text { strength }\end{array}$ & $\begin{array}{l}\text { Effective } \\
\text { cohesion }\end{array}$ & $\begin{array}{l}\text { Internal } \\
\text { friction } \\
\text { angle }\end{array}$ & $\begin{array}{l}\text { Deformation } \\
\text { module }\end{array}$ & $\begin{array}{l}\text { Thrust at } \\
\text { rest } \\
\text { coefficient }\end{array}$ & $\begin{array}{l}\text { Poisson's } \\
\text { coefficient }\end{array}$ \\
\hline & $\begin{array}{c}\gamma_{\mathrm{ap}} \\
\left(\mathrm{kN} / \mathrm{m}^{3}\right)\end{array}$ & $\begin{array}{c}\mathrm{q}_{\mathrm{u}} \\
(\mathrm{MPa})\end{array}$ & $\begin{array}{c}\mathrm{c}^{\prime} \\
(\mathrm{kPa})\end{array}$ & $\begin{array}{l}\varnothing^{\prime} \\
\left({ }^{\circ}\right)\end{array}$ & $\begin{array}{c}\mathrm{E} \\
(\mathrm{MPa})\end{array}$ & $\mathrm{k}_{\mathrm{o}}$ & $\mathrm{v}$ \\
\hline $\begin{array}{c}\text { Ampurdán } \\
\text { Claystone } \\
\text { Formation } \\
\left(\mathrm{M}_{\mathrm{A}}\right)\end{array}$ & 21 & 0.36 & 40 & 30 & 200 & 0.8 & 0.3 \\
\hline
\end{tabular}

Table 2 Summary of support types used in Ampurdán tunnel.

\begin{tabular}{ccccccc}
\hline $\begin{array}{c}\text { Section } \\
\text { type }\end{array}$ & Terrain & $\begin{array}{c}\text { Length } \\
(\mathrm{m})\end{array}$ & RMR & Zone / phases; passes & $\begin{array}{c}\text { Shotcrete with fibers } \\
(\mathrm{cm})\end{array}$ & Steel ribs \\
\hline S-III & $\mathrm{M}_{\mathrm{A}}$ & 505 & $20-30$ & $\begin{array}{c}\text { Top heading / 1; 0.5-1 m } \\
\text { Bench / } 2 ; 1-2 \mathrm{~m}\end{array}$ & 5 seal + 30 HM-35 & HEB-160 \\
SE & Portals & $2 \times 60$ & 20 & $\begin{array}{c}\text { Top heading / 1; 0.5-1 m } \\
\text { Bench / } 2 ; 1-2 \mathrm{~m}\end{array}$ & 5 seal + 30 HM-35 & HEB-180 \\
\hline
\end{tabular}

Table 3 Initial parameters used in the calculations

\begin{tabular}{ccccccc}
\hline Formation & $\begin{array}{c}\text { Apparent } \\
\text { density } \\
\gamma_{\mathrm{ap}} \\
\left(\mathrm{kN} / \mathrm{m}^{3}\right)\end{array}$ & $\begin{array}{c}\text { Residual } \\
\text { cohesion } \\
\mathrm{c}_{\mathrm{r}} \\
(\mathrm{kPa})\end{array}$ & $\begin{array}{c}\text { Residual } \\
\text { friction angle } \\
\emptyset_{\mathrm{r}} \\
\left({ }^{\circ}\right)\end{array}$ & $\begin{array}{c}\text { Secant } \\
\text { modulus } \\
\mathrm{E}_{50} \\
(\mathrm{MPa})\end{array}$ & $\begin{array}{c}\text { Angle of } \\
\text { dilatancy } \\
\psi\end{array}$ & $\begin{array}{c}\text { Poisson's } \\
\text { coefficient }\end{array}$ \\
\hline $\begin{array}{c}\text { Ampurdán } \\
\text { Claystone }\end{array}$ & 21 & 40 & 30 & 200 & 5 & 0.2 \\
Formation $\left(\mathrm{M}_{\mathrm{A}}\right)$ & & & & & 5 \\
\hline
\end{tabular}

Table 4 Values considered for the parametric study and sequential reduction for each parameter

\begin{tabular}{cccccccccc}
\hline Study & $\begin{array}{c}\Delta \text { R.F. } \\
(\%)\end{array}$ & $\begin{array}{c}\gamma_{\mathrm{ap}} \\
(\mathrm{kN} / \mathrm{m}\end{array}$ & $\begin{array}{c}\Delta \text { R.F. } \\
(\%)\end{array}$ & $\begin{array}{c}\mathrm{c}_{\mathrm{r}} \\
(\mathrm{kPa})\end{array}$ & $\begin{array}{c}\Delta \text { R.F. } \\
(\%)\end{array}$ & $\begin{array}{c}\phi_{\mathrm{r}} \\
\left({ }^{\circ}\right)\end{array}$ & $\begin{array}{c}\Delta \text { R.F. } \\
(\%)\end{array}$ & $\begin{array}{c}\mathrm{E}_{50} \\
(\mathrm{MPa})\end{array}$ & $\begin{array}{c}\text { Cohesive soil } \\
\text { consistency }\end{array}$ \\
\hline 1 & 0 & 21.0 & 0 & 40.0 & 0 & 30.0 & 0 & 200 & \\
2 & 0 & 21.0 & 0 & 100.0 & 0 & 35.0 & 0 & 200 & - \\
3 & 1 & 20.8 & 5 & 95.0 & 1 & 34.7 & 7 & 186 & - \\
4 & 2 & 20.4 & 10 & 85.5 & 2 & 34.0 & 14 & 160 & - \\
5 & 3 & 19.8 & 15 & 72.7 & 3 & 32.9 & 21 & 126 & - \\
6 & 4 & 19.0 & 20 & 58.1 & 4 & 31.6 & 28 & 91 & Stiff \\
7 & 5 & 18.0 & 25 & 43.6 & 5 & 30.0 & 35 & 59 & Stiff \\
8 & 6 & 16.9 & 30 & 30.5 & 6 & 28.2 & 42 & 34 & Medium \\
9 & 7 & 15.8 & 35 & 19.8 & 7 & 26.3 & 49 & 17 & Medium \\
10 & 8 & 14.5 & 40 & 11.9 & 8 & 24.2 & 56 & 7.7 & Soft \\
\hline
\end{tabular}

$\Delta$ R.F. $=$ Reduction Factor in consecutive Studies 
Table 5 Accumulated deformation in the crown for the studies performed

\begin{tabular}{ccccccc}
\hline \multicolumn{7}{c}{ Deformation in the crown $(\mathrm{mm})$} \\
Study & F1 & F2 & F3 & F4 & F5 & F6 \\
\hline 2 & 5.3 & 11.5 & 11.6 & 13.8 & 13.8 & 14.1 \\
3 & 5.5 & 12.0 & 12.0 & 14.8 & 14.4 & 15.4 \\
4 & 5.9 & 14.0 & 14.4 & 15.0 & 16.7 & 18.9 \\
5 & 6.6 & 14.0 & 14.0 & 19.0 & 19.0 & 22.0 \\
6 & 7.7 & 16.0 & 17.0 & 30.0 & 29.0 & 3.02 \\
7 & 9.0 & 20.0 & 19.0 & 60.0 & 65.0 & 65.0 \\
8 & 11.0 & 35.0 & 30.0 & 240.0 & 240.0 & - \\
9 & 15.0 & 120.0 & - & - & - & - \\
10 & 20.0 & - & - & - & - & - \\
\hline \multicolumn{7}{c}{} \\
\hline
\end{tabular}

Table 6 Comparison between assumed intact parameters and computed parameters at failure of Ampurdán claystone Formation $\mathrm{M}_{\mathrm{A}}$

\begin{tabular}{ccccc}
\hline $\begin{array}{c}\text { Ampurdán Claystone } \\
\text { Formation (MA) }\end{array}$ & $\begin{array}{c}\text { Apparent } \\
\text { density }\end{array}$ & $\begin{array}{c}\text { Residual } \\
\text { cohesion } \\
\gamma_{\mathrm{ap}}\end{array}$ & $\begin{array}{c}\text { Residual } \\
\text { friction } \\
\text { angle }\end{array}$ & $\begin{array}{c}\text { Secant } \\
\text { modulus }\end{array}$ \\
\hline $\begin{array}{c}\mathrm{c}_{\mathrm{r}} \\
(\mathrm{kPa})\end{array}$ & $\begin{array}{c}\emptyset_{\mathrm{r}} \\
\left({ }^{\circ}\right)\end{array}$ & $\begin{array}{c}\mathrm{E}_{50} \\
(\mathrm{MPa})\end{array}$ \\
$\begin{array}{c}\text { Assumed intact } \\
\text { parameters } \\
\text { (Study 2) }\end{array}$ & 21.0 & 100 & 35 & 200 \\
$\begin{array}{c}\text { Computed parameters } \\
\text { at failure } \\
\text { (Study 10) }\end{array}$ & 14.5 & 11.9 & 24.2 & 7.7 \\
$\begin{array}{c}\text { \% of initial } \\
\text { parameters at failure }\end{array}$ & $69 \%$ & $12 \%$ & $69 \%$ & $4 \%$ \\
\hline
\end{tabular}

